\title{
UKRAINIAN CULTURE
}

\author{
DOI https://doi.org/10.30525/978-9934-26-117-6-8
}

\section{ІСТОРИКО-ТЕОРЕТИЧНИЙ ФАКУЛЬТЕТ КИЇВСЬКОЇ КОНСЕРВАТОРІЇ: СТАНОВЛЕННЯ Й РОЗВИТОК (1930-ТІ РОКИ)}

\author{
Гнатюк Л. А. \\ кандидат мистецтвознавства, доцент, \\ професор кафедри історії світової музики і кафедри історії \\ украӥнськоӥ музики та музичної фольклористики \\ Національна музична академія України імені П. І. Чайковського \\ м. Київ, Украӥна
}

Історико-теоретичний i композиторський факультет у Київській консерваторії засновано 1934 року. Його історія починається від створеного наприкінці 1922/1923 навчального року науково-теоретичного факультету: його заснування ініціював ще 1920 року Кирило Стеценко, який працював тоді в Консерваторії (викладав хоровий спів) та Музично-драматичному інституті імені М. В. Лисенка (читав курс бібліографії хорової літератури) ${ }^{1}$. Серед організаторів науково-теоретичного факультету - Арнольд Альшванг. Факультет очолив фахівець із теорії та історії мистецтва Федір Шміт (Шмідт), який читав курси психології та стилістики мистецтва (1921-1924).

Активна наукова й педагогічна діяльність викладачів Київської консерваторії у 1920-ті роки виявилася важливим підгрунтям, завдяки якому стало можливим утворення відповідного факультету. У цьому підготовчому процесі провідну роль відіграли викладачі музичнотеоретичних дисциплін. Вони ввели у навчальний обіг нові дисципліни, удосконалили й оптимізували викладання традиційних освітніх курсів. Більшість митців були авторами навчально-методичних праць, які стали результатом тривалого педагогічного досвіду, чи наукових досліджень, матеріали яких активно впроваджували в навчальну практику. Одним із таких нових, національно зорієнтованих предметів стала історія української музики. Перші ऑiі викладачі - музикознавець

${ }^{1}$ У Музично-драматичному інституті імені М. В. Лисенка аналогічний факультет засновано 1924 року. 
i композитор Пилип Козицький та вчений, фундатор українського історичного музикознавства Микола Грінченко - у навчальному процесі застосовували результати своїх досліджень. Новітні ідеї дипломної роботи «Спів і музика в Київській академії за 300 років іiі існування» ${ }^{2}$ (1917) випускника Києво-Могилянської академії (1917) та Київської консерваторії (1918) П. Козицького становили основу його курсу історії української музики й загалом концепції цього предмета, відображеній у численних навчальних програмах і «Конспекті (схемі) лекцій з історії української музики» [4] (1928). Серед важливих ідей ученого, які й досі не втратили свого значення: розвиток музичноосвітньої справи можливий лише за умови державної підтримки; період навчання для майбутнього фахівця $є$ найважливішим, визначальним для всього його життя; освіта взагалі й національна зокрема $є$ гарантію державної безпеки, запорукою національної незалежності, ознакою цивілізованості народу [5].

М. Грінченко, вихованець Київського музичного училища (1912) і Кам'янець-Подільського університету (1920), є автором «Історії української музики» [1] (1922) - першого фундаментального музичноісторичного дослідження й водночас підручника з історії української музики. У цій праці охоплено широкий історичний період (від найдавніших часів до 1920-х років), розглянуто практично всі жанри української музики, висвітлено творчість українських митців. Підготовлений до друку новий, суттєво розширений і доповнений (1062 аркуші) варіант праці [2] (1928) так і не був опублікований: учений зазнав репресій, а його книга - нищівної критики, її було вилучено з навчального обігу. Однак обидва варіанти (і виданий, і рукописний) стали концепційною основою практично для всіх наступних досліджень з історії української музики, матеріали активно цитувалися (правда, без зазначення імені М. Грінченка) у музично-історичних працях наступних поколінь мистецтвознавців. Важливе наукове й педагогічне значення мають інші дослідження вченого, особливо «Український музичний словник», задуманий як грунтовне тритомне видання, призначене «всім, хто працює в галузі української музичної культури - педагогам, композиторам, музикознавцям, фольклористам, виконавцям і широкій масі студентів консерваторії» [3, од. зб 559, арк. 2]. Важливими для розвитку українського історичного музикознавства і педагогіки були й

${ }^{2}$ Цю працю П. Козицького було опубліковано лише 1971 року [5]. Вона стала першим в українському музикознавстві грунтовним дослідженням із питань історії української музичної освіти. 
інші праці П. Козицького та М. Грінченка з різних питань музичного мистецтва, життя і творчості українських митців.

Велике практичне значення для вихованців молодших класів консерваторій та інших музичних навчальних закладів мав підручник «Руководство к практическому изучению элементарной теории музыки...» (1906) Григорія Любомирського [8]. Праця має яскраве практичне спрямування і $\epsilon$ результатом тривалого педагогічного досвіду іiі автора: вона зазнавала змін та доповнень у кожному з трьох іiі перевидань (1913, 1924, 1930). В іншому підручнику, «Руководстве к практическому изучению гармонии...» [9] (1909-1913) Г. Любомирський спирається на основні положення аналогічних навчальних посібників своїх учителів - М. Римського-Корсакова й особливо А. Аренського. Творчі завдання, запропоновані в підручнику (зокрема створення модуляційних прелюдів), є підтвердженням високого рівня музичнотеоретичної підготовки учнів Г. Любомирського.

Після реорганізації музичної освіти, утворення Київської консерваторії та заснування історико-теоретичного і композиторського факультету (1934) справу М. Грінченка і П. Козицького продовжив Андрій Ольховський, який у 1935-1941 роках очолював одну із двох кафедр новоствореного факультету - історії музики. В цей період у країні суттєво активізується навчально-методична сфера, ініціюється створення навчальної літератури з музично-історичних і теоретичних дисциплін. На науково-методичній конференції (Київ, 1939) після всесоюзного обговорення затверджено «Тематичний план курсу історії української музики» [11] Андрія Ольховського. Згодом за цим планом опубліковано підручник «Нарис історії української музики» ${ }^{3}$ [10] (1941). Дотримуючись необхідних на той час «ідеологічно витриманих позицій», автор скористався здобутками попередників і сучасників (зокрема й колег по кафедрі), широко висвітлив важливі ключові питання української музичної культури. Однак через еміграцію А. Ольховського працю було вилучено 3 навчального обігу, а ім'я автора забуто.

Новостворену кафедру теорії музики i композиції очолив український композитор і педагог Борис Лятошинський. Поряд із ним викладають композицію та музично-теоретичні дисципліни провідні митці України Лев Ревуцький, Віктор Косенко, Михайло

${ }^{3}$ У перші дні бойових дій у Києві під час Другої світової війни весь тираж згорів, крім одного примірника, що зберігся в автора. «Нарис...» перевидано 2003 року. Докладніше див. праці Лідії Корній [6; 7, с. 67-76]. 
Скорульський, Гліб Таранов, музиканти-теоретики Григорій Любомирський, Всеволод Павкович, Фріда Аерова. Усі вони із власне педагогічною провадили й літературну та наукову діяльність, були авторами музично-теоретичних посібників та підручників, наукових праць із різних питань музичного мистецтва.

Опублікована й рукописна навчально-методична і наукова спадщина педагогів та вихованців Київської консерваторії демонструє їхні різнобічні мистецькі зацікавлення, а також є вагомим внеском у різні сфери музикознавства та музичної педагогіки, серед яких: історія зарубіжної та української музики (М. Грінченко, П. Козицький, А. Ольховський), історія світової та української культури (М. Грінченко, П. Козицький, А. Гозенпуд), музична фольклористика (М. Грінченко), творчість українських та зарубіжних композиторів (М. Грінченко, П. Козицький, М. Гейліг, Ф. Аерова), теорія музики, гармонія, поліфонія, аналіз музичних творів (Г. Любомирський, В. Павкович, М. Скорульський, Л. Хінчин, В. Стеценко); інструментування й читання партитур (Г. Таранов); музична бібліографія (М. Грінченко); методика викладання музично-теоретичних та інших дисциплін (П. Козицький, Г. Любомирський, В. Павкович, М. Скорульський).

Підсумовуючи, зазначимо: у 1930-х роках історико-теоретичний i композиторський факультет Київської консерваторії став провідним музично-науковим осередком, завдяки різнобічній діяльності викладачів сформувалася потужна українська наукова музикознавча й музично-педагогічна школа, що дало змогу 1934 року відкрити відділ аспірантури.

\section{Література:}

1. Грінченко М. О. Історія української музики. Київ : Спілка, 1922. $290 \mathrm{c}$.

2. Грінченко М. О. Історія української музики [Рукопис]. Інститут мистеитвознавства, фольклористики та етнології (далі ІІМФЕ) імені М. Т. Рильського. Ф. 36 I-ІІІ. Од. зб. 139. 1062 арк.

3. Грінченко М. О. Український музичний словник. IMФE ім. М. Т. Рильського. Ф. 36 I-IV. Од. зб. 551-559.

4. Козицький П. О. Конспект (схема) лекцій з історії української музики. Музика-масам. 1928. № 3/4. С. 36-37; № 7. С. 14-15.

5. Козицький П. О. Спів і музика в Київській академії за 300 років iii існування. Київ, 1971. 148 с.

6. Корній Л. П. Андрій Ольховський i його «Нарис історії української музики». Ольховський А. В. Нарис історії української 
музики / підгот. до вид., наук. ред., вступ. ст., комент. Л. П. Корній ; літ. ред. Г. П. Півторака. Київ : Муз. Україна, 2003. С. 29-46.

7. Корній Л. П. Джерелознавство історії української музичної культури. Київ : ІМФЕ ім. М. Т. Рильського, 2019. 312 с.

8. Любомирський Г. Л. Практичний підручник елементарної теорії музики 3 додатком «Музикальний слух, його виховання та удосконалення» для учнів музичних шкіл і самоосвіти. Вид. 4-те. Київ : К.М.П, 1930. 108 с.

9. Любомирский Г. Л. Руководство к практическому изучению гармонии, приспособленное к самообучению и изложенное в 32 уроках. Курс 1-2. Киев : Изд. Л. Идзиковского, 1909-1913. Друге вид.: Курс 1. Киев ; Варшава : Изд. Л. Идзиковского, 1914. 142 с. Курс 2. Киев : Изд. Л. Идзиковского, 1913, 146 с.

10. Ольховський А. В. Нарис історії української музики / під ред. Ігоря Глебова [Б. В. Асаф’єва]. Київ : Мистецтво, 1941. 354 с.

11. Ольховський А. В. Тематичний план курсу історії української музики. Радянська музика. 1938. № 5. С. 18-28.

DOI https://doi.org/10.30525/978-9934-26-117-6-9

\title{
ДУХОВНА ХОРОВА ТВОРЧІСТЬ МИРОСЛАВА СКОРИКА В КОНТЕКСТІ ПОСТРАДЯНСЬКОГО МУЗИЧНОГО ПРОСТОРУ
}

\author{
Гусарчук Т. В. \\ доктор мистецтввознавства, \\ доцент, професор кафедри історії української музики \\ та музичної фольклористики \\ Національна музична академія Украйни імені П. І. Чайковського \\ м. Київ, Україна
}

Однією з найяскравіших тенденцій розвитку музичного мистецтва наприкінці XX - у перші десятиліття XXI століття став розквіт жанрів духовної музики, пов'язаний 3 ментальними пошуками, потребою в духовному оперті, поверненням до джерел національної культури.

У незалежній Україні міленіум відкрив нову золоту добу хорової творчості, тісно пов'язаної з духовною проблематикою і відповідними жанрами. До Лесі Дичко, яка ще наприкінці 1980-х років започаткувала цей новий напрямок, долучилися видатні майстри різних поколінь - 